\title{
ANALISIS MIKROPLASTIK DI INSANG DAN SALURAN PENCERNAAN IKAN KARANG DI TIGA PULAU KECIL DAN TERLUAR PAPUA, INDONESIA: KAJIAN AWAL
}

\section{MICROPLASTICS ANALYSIS IN THE GILL AND GASTROINTESTINAL TRACT OF CORAL REEF FISHES FROM THREE SMALL OUTER ISLANDS OF PAPUA, INDONESIA: A PRELIMINARY STUDY}

\author{
Defri Yona ${ }^{1,2^{*}}$, Mela Dita Maharani ${ }^{1,2}$, M. Reza Cordova ${ }^{3}$, Yuyun Elvania ${ }^{1}$, \\ \& I Wayan Eka Dharmawan ${ }^{3}$ \\ ${ }^{1}$ Program Studi Ilmu Kelautan, FPIK, Universitas Brawijaya, Malang, 65145, Indonesia \\ ${ }^{2}$ MEXMA Research Group, FPIK, Unversitas Brawijaya, Malang, 65145, Indonesia \\ ${ }^{3}$ Pusat Penelitian Oseanografi (P2O), LIPI, Jakarta, 14430, Indonesia \\ *E-mail: defri.yona@ub.ac.id
}

\begin{abstract}
Microplastics have been found widely in marine environments, including the remote areas far from human activities, and can be ingested by fish. This study aimed to investigate microplastics from 12 coral reef fishes of three small outer islands of Papua (Liki, Befondi, and Miossu) and to analyze the difference of microplastic concentrations in gill and gastrointestinal tract. Fish samples were obtained using a hand line and dissected to separate the gills and gastrointestinal tracts. The destruction method using $\mathrm{H} 2 \mathrm{O} 230 \%$ was conducted to separate organic matter, and the microscope was used to identify microplastic types. Fibers were found in all fish species in the range of 1.60-28.30 particle/g dry weight. Microplastics in fishes from Liki Island were higher compared to the ones from Befondi and Miossu Islands. The results of this study observed that there is no relationship between fish size and microplastic concentration since the size of fishes from Liki Island were smaller than the ones from the two islands. Most fishes were observed to contain fiber in both the gill and gastrointestinal tract, with the dominant size of microplastic was > $1000 \mu \mathrm{m}$. This study found that microplastics in the gills were higher than in the gastrointestinal tracts, and it is related to the difference in the organ functionality and the process of microplastic entering the organs from the surrounding water.
\end{abstract}

Keywords: microplastics, organs, Papua, small outer island

\begin{abstract}
ABSTRAK
Keberadaan mikroplastik di perairan dapat berpotensi masuk pada organisme perairan termasuk ikan. Penelitian ini bertujuan untuk mengungkap keberadaan mikroplastik pada 12 ikan terumbu karang yang ditangkap dari perairan di tiga pulau kecil dan terluar Papua (Pulau Liki, Befondi dan Miossu) dan menganalisis perbedaan mikroplastik yang ditemukan pada insang dan saluran pencernaannya. Ikan ditangkap dengan alat pancing dan dipisahkan organ insang dan saluran pencernaannya untuk dianalisis jenis mikroplastiknya. Destruksi bahan organik dilakukan dengan menggunakan larutan $\mathrm{H}_{2} \mathrm{O}_{2} 30 \%$ dan identifikasi mikroplastik dilakukan menggunakan mikroskop. Diantara jenis mikroplastik, hanya jenis fiber yang ditemukan di semua spesies ikan dengan kisaran 1,60-28,30 partikel/g berat kering. Mikroplastik yang ditemukan pada ikan yang ditangkap dari Pulau Liki lebih tinggi jika dibandingkan dengan di Pulau Befondi dan Miossu. Penelitian ini menemukan bahwa ukuran ikan tidak memengaruhi keberadaan mikroplastik pada ikan. Ikan-ikan yang ditangkap dari Pulau Liki berukuran lebih kecil jika dibandingkan dengan ikan yang ditangkap dari Pulau Befondi dan Miossu. Sebagian besar ikan yang ditemukan, mengandung fiber pada insang dan saluran pencernaan dengan ukuran yang dominan adalah $>1000 \mu \mathrm{m}$. Kelimpahan mikroplastik jenis fiber lebih tinggi pada insang dibandingkan pada saluran pencernaan dan hal ini diduga karena perbedaan fungsi antar organ dan proses masuknya mikroplastik dari perairan ke organ-organ tersebut.
\end{abstract}

Kata kunci: mikroplastik, organ, Papua, pulau kecil dan terluar 


\section{PENDAHULUAN}

Mikroplastik adalah komponen plastik dengan ukuran kecil $(<5 \mathrm{~mm})$ yang sebagian besar berasal dari penguraian plastik-plastik berukuran besar (Andrady, 2011; GESAMP, 2015). Mikroplastik jenis ini dikategorikan sebagai mikroplastik sekunder karena tidak secara sengaja dibuat menjadi berukuran kecil. Namun demikian, ada juga mikroplastik yang memang dibuat berukuran kecil yang disebut sebagai mikroplastik primer dan biasanya menjadi bahan baku pembuatan plastik (pellet) atau sebagai bahan dasar beberapa kosmetik (scrub) (GESAMP, 2016). Jenis yang paling banyak mencemari lingkungan adalah mikroplastik sekunder seperti fragmen, fiber dan juga film (Andrady, 2011).

Menurut beberapa sumber penelitian (Hidalgo-Ruz et al., 2012; Zobkov \& Esiukova, 2017; Dai et al., 2018), fragmen adalah partikel plastik yang tidak dapat dihancurkan dengan menggunakan pinset dan cenderung memiliki bentuk yang tidak beraturan dengan ujung-ujung yang tajam. Selanjutnya fiber dapat dikenali dari bentuknya yang cenderung memanjang dengan ketebalan yang hampir sama, sedangkan film merupakan lembaran-lembaran tipis yang berasal dari plastik-plastik kemasan. Fragmen, fiber dan film dapat bersumber dari berbagai jenis plastik yang sebagian besar akibat penggunaan dari kegiatan domestik (Frère et al., 2017; Zhao et al., 2018; Yona et al., 2019). Selain itu, secara spesifik jenis fiber juga dapat bersumber dari kegiatan perikanan dalam bentuk uraian dari alat tangkap seperti jaring dan jala (Zhu et al., 2018).

Karena ukurannya yang sangat kecil, mikroplastik dapat memberikan dampak yang cukup besar terhadap makhluk hidup termasuk manusia. Telah banyak penelitian yang dilakukan untuk mengetahui keberadaan mikroplastik pada berbagai organisme di laut, seperti kerang-kerangan (Woods et al., 2018), udang (Abbasi et al., 2018) dan juga ikan (Jabeen et al., 2017; Baalkhuyur et al., 2018). Hal ini terjadi karena mikroplastik dapat tertelan oleh biota-biota tersebut dalam prosesnya mencari makan secara tidak sengaja karena bentuknya yang hampir sama dengan jenis makanannya (Neves et al., 2015), atau karena mangsanya juga telah terkontaminasi oleh mikroplastik. Pada ikan, organ tubuh yang dapat terpapar mikroplastik diantaranya adalah insang, saluran pencernaan maupun lambung. Sebagian besar hasil penelitian menyebutkan bahwa keberadaan mikroplastik pada saluran pencernaan ikan dianggap sebagai tempat terakumulasinya mikroplastik (Murphy et al., 2017; Baalkhuyur et al., 2018; Giani et al., 2019; Savoca et al., 2019), namun belum banyak penelitian yang melihat keberadaan mikroplastik pada insang. Insang juga berpotensi mengandung mikroplastik karena organ ini berfungsi sebagai tempat keluar masuknya air dalam proses pernapasan ikan (Su et al., 2019). Saluran pencernaan diduga menjadi tempat terakumulasinya mikroplastik sebagai bagian dari proses makan ikan.

Keberadaan mikroplastik tidak hanya ditemukan pada wilayah-wilayah perairan yang dekat dengan kegiatan manusia, namun juga dapat ditemukan di laut lepas, dasar laut dan juga pulau-pulau terpencil yang jauh dari kegiatan manusia (Cordova \& Wahyudi, 2016; Cincinelli et al., 2017; Imhof et al., 2017; Isobe et al., 2017; Zobkov \& Esiukova, 2017). Hal ini terjadi karena pergerakan mikroplastik dapat dipengaruhi oleh faktorfaktor oseanografi seperti arus dan gelombang (Iwasaki et al., 2017) sehingga dapat berpindah dalam jarak yang sangat luas dan jauh dari sumber pencemarnya. Pulau-pulau kecil dan terluar di wilayah Papua termasuk dalam pulau-pulau yang cukup rentan terhadap keberadaan mikroplastik. Selain berpotensi mendapat pencemaran mikroplastik dari kegiatan manusia di Papua, pulau-pulau ini juga berpotensi mendapat masukan mikroplastik dari Samudra Pasifik. Oleh karena itu, penelitian ini dilaksanakan untuk mengungkap keberadaan mikroplastik pada 
ikan-ikan karang yang ditemukan di tiga pulau terluar Papua dan menganalisis perbedaan keberadaan mikroplastik pada insang dan saluran pencernaan ikan-ikan tersebut.

\section{MATERIAL DAN METODE}

\subsection{Waktu dan Tempat}

Penelitian ini merupakan bagian dari Ekspedisi Nusa Manggala (ENM) di kawasan pesisir pulau-pulau kecil terluar Indonesia di wilayah Samudra Pasifik oleh Pusat Penelitian Oseanografi (P2O) LIPI. Tiga pulau yang menjadi daerah penelitian ini adalah Pulau Liki, Pulau Befondi dan Pulau Miossu (Figure 1). Pulau Liki dan Pulau Befondi berada di Provinsi Papua dihuni oleh penduduk berjumlah berkisar 50-120 KK, sedangkan Pulau Miossu, Provinsi Papua Barat tidak berpenghuni. Pulau-pulau ini memiliki potensi sumber daya perikanan termasuk ikan-ikan karang. Pengambilan sampel ikan dilaksanakan pada tanggal 20
November-2 Desember 2018.

\subsection{Metode Pengambilan Sampel Ikan}

Sampel ikan diambil dengan alat pancing di Pulau Liki tanggal 20 November 2018, Pulau Befondi tanggal 26 November 2018 dan Pulau Miossu tanggal 2 Desember 2018. Sampel ikan selanjutnya diidentifikasi menggunakan buku Reef Fish Identification: Tropical Pacific (Allen et al., 2003) dan juga website fishbase (http://www.fishbase.org). Lima ekor diperoleh di Pulau Liki yang terdiri dari Myripristis hexagona (3 ekor), Surgocentron caudimaculatum (1 ekor) dan Cephalopolis urodeta (1 ekor). Lima ekor ikan juga diperoleh dari Pulau Befondi yaitu Lutjanus kasmira (2 ekor), Balistapus undulatus (1 ekor), Lutjanus gibbus (1 ekor) dan $S$. caudimaculatum (1 ekor). Dua ekor diperoleh dari Pulau Miossu dengan jenis spesies yang sama yaitu L. xanthopinnis, sehingga total keseluruhan ikan dari ketiga pulau yang dianalisis kandungan mikroplastiknya adalah 12 ekor (Table 1).

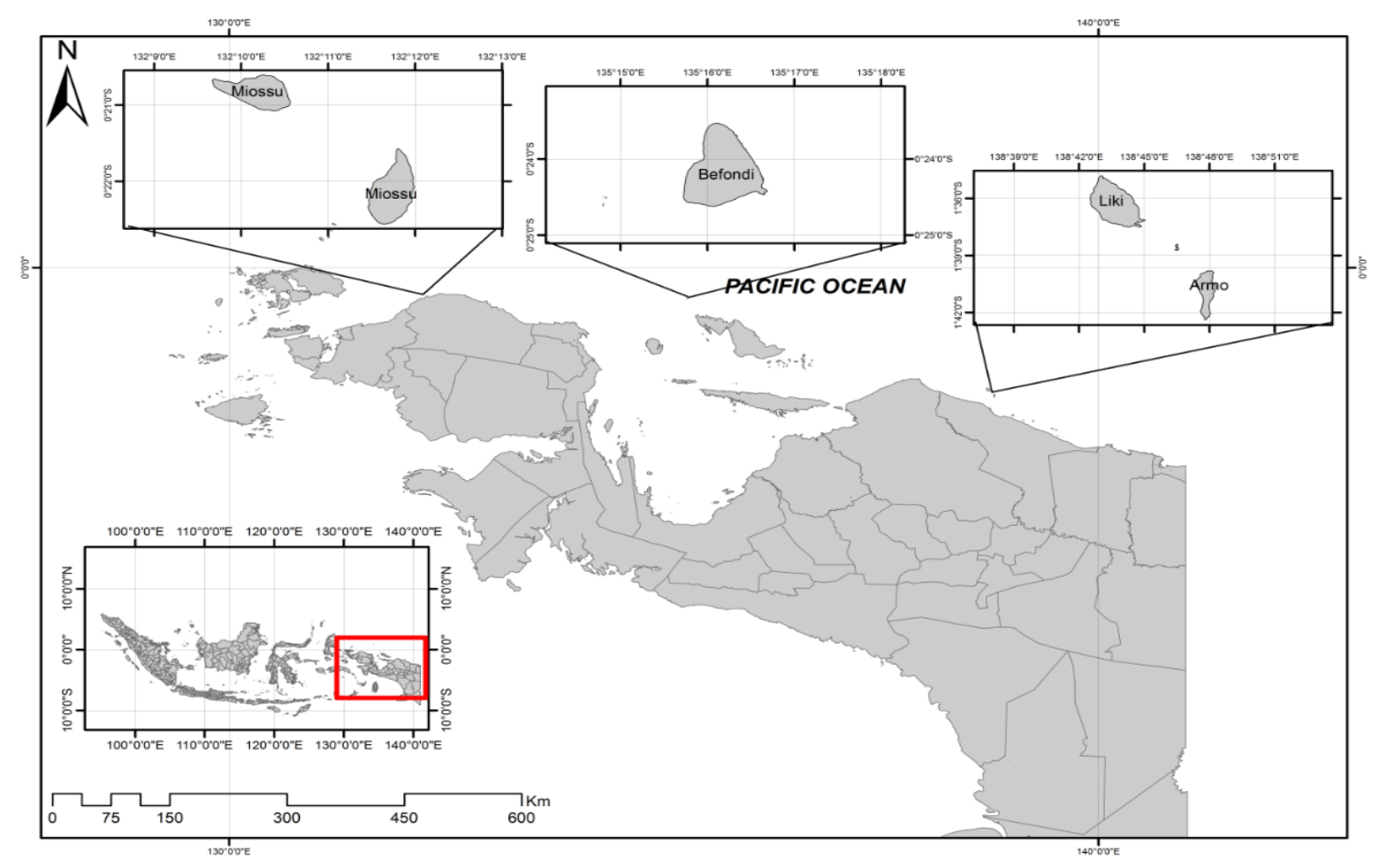

Figure 1. Map showing the three small outer islands of Papua where the coral reef fishes were obtained. 


\subsection{Analisis Mikroplastik pada Sampel Ikan}

Seluruh sampel ikan dimasukkan ke dalam pembeku sebelum dianalisis. Pada saat di laboratorium, sampel ikan diukur panjang (cm) menggunakan penggaris dan berat ikan (g) diukur menggunakan timbangan analitik (Table 1). Analisis mikroplastik dilakukan pada dua organ ikan yaitu bagian insang dan saluran pencernaan. Sebelum analisis mikroplastik, masing-masing organ insang dan saluran pencernaan ditimbang berat basah, kadar air dan berat keringnya. Selanjutnya sampel insang dan saluran pencernaan dari setiap spesies ikan didestruksi dengan merendam sampel pada larutan $\mathrm{H}_{2} \mathrm{O}_{2} 30 \%$ selama 24 jam. Proses destruksi dilanjutkan dengan meletakkan sampel pada waterbath pada suhu $70{ }^{\circ} \mathrm{C}$ selama 24 jam sampai berubah bening. Pemisahan bahan organik pada sampel dilakukan dengan penyaringan menggunakan cellulose nitrate filter berpori $0,45 \mu \mathrm{m}$ dan kertas saring dikeringkan dengan oven pada suhu $60^{\circ} \mathrm{C}$ selama 24 jam.

Identifikasi jenis mikroplastik beserta ukurannya dilakukan dengan menggunakan mikroskop merk Nikon Olympus $\mathrm{CH}-2$. Jenis mikroplastik dibedakan menjadi fragmen, film dan fiber (Hidalgo-Ruz et al., 2012; Mohamed Nor \& Obbard, 2014; Zobkov \& Esiukova, 2017; Dai et al., 2018). Ukuran mikroplastik dibedakan menjadi empat kategori, yaitu $<300 \mu \mathrm{m}, 300-500 \mu \mathrm{m}, 500-1000$ $\mu \mathrm{m}$ dan $<1000 \mu \mathrm{m}$. Alat-alat yang digunakan telah dipastikan steril untuk menghindari kontaminasi dan semua sampel selalu ditutup dengan aluminium foil jika tidak sedang digunakan.

\section{HASIL DAN PEMBAHASAN}

Jenis ikan yang dianalisis pada penelitian ini adalah ikan-ikan karang karena pulau-pulau kecil terluar di wilayah Papua kaya akan potensi ikan karang (Hasil Penelitian Ekspedisi Nusa Manggala). Ekosistem terumbu karang rentan terhadap pencemaran mikroplastik yang bersumber dari kegiatan manusia di daratan maupun masukan dari laut akibat pergerakan massa air seperti gyre (Connors, 2017). Lebih lanjut, Cordova et al. (2018) menemukan potensi masukan mikroplastik pada sedimen di ekosistem terumbu karang Sekotong, Lombok akibat pengaruh Arus Lintas Indonesia (Arlindo). Meskipun Pulau Liki, Befondi dan Miossu termasuk dalam kategori pulau-pulau kecil dan terluar yang cenderung jauh dari kegiatan manusia, namun potensi pencemaran mikroplastik tetap dapat terjadi dan beresiko juga terhadap ikan-ikan yang hidup di perairannya.

Seluruh sampel ikan ditemukan mengandung mikroplastik dan hanya ditemukan jenis fiber (Figure 2). Jenis mikroplastik seperti fragmen maupun film yang biasanya mendominasi ekosistem perairan tidak ditemukan. Dominansi fiber pada ikan ini seperti yang ditemukan pada beberapa penelitian ikan tangkapan di perairan pantai dan perairan tawar di China (Jabeen et al., 2017), pada ikan-ikan karang di sepanjang Laut Merah Saudi Arabia (Baalkhuyur et al., 2018) dan pada ikan konsumsi di Laut Mediterania (Giani et al., 2019). Fiber termasuk jenis mikroplastik yang mendominasi di kolom perairan karena jenis ini banyak bersumber dari kegiatan domestik seperti pencucian pakaian maupun kegiatan perikanan (Bessa et al., 2018; Zhu et al., 2018; Yona et al., 2019). Pozo et al. (2019) dalam penelitiannya menemukan bahwa ikan-ikan yang hidup di perairan pantai yang dekat dengan kegiatan manusia cenderung rentan terpapar oleh mikroplastik jenis fiber. Hal ini juga yang dapat menjadi alasan ditemukannya mikroplastik jenis fiber pada ikan karang di wilayah perairan Papua.

Kelimpahan total mikroplastik jenis fiber pada penelitian ini ditemukan dengan nilai yang bervariasi antar ikan di setiap pulau (Table 2), berkisar dari kelimpahan terendah pada ikan L. gibbus dari Pulau Befondi (1,60 partikel/g) dan kelimpahan tertinggi pada ikan $S$. caudimaculatum yang ditangkap di Pulau Liki (28,30 partikel/g). 
Secara keseluruhan, kelimpahan total mikroplastik ditemukan lebih tinggi pada ikan-ikan yang tertangkap dari Pulau Liki, diikuti dengan ikan dari Pulau Miossu dan Pulau Befondi. Meskipun ukuran ikan yang tertangkap di Pulau Befondi lebih besar dibandingkan ikan yang tertangkap dari Pulau Liki dan Miossu (Table 1), namun rendahnya keberadaan mikroplastik pada ikan di pulau ini dapat dikaitkan dengan kemungkinan lebih rendahnya keberadaan mikroplastik di perairan. Selain itu, beberapa penelitian telah menemukan faktor yang memengaruhi keberadaan mikroplastik pada ikan seperti habitat, kebiasaan makan, ukuran, densitas dan sumber mikroplastik di perairan (Neves et al., 2015; Jabeen et al., 2017;
Baalkhuyur et al., 2018; Giani et al., 2019; Sarasita et al., 2020) yang juga kemungkinan dapat memengaruhi perbedaan kelimpahan mikroplastik antar ikan pada ketiga pulau.

Mikroplastik jenis fiber ditemukan baik pada insang maupun saluran pencernaan pada ketiga spesies ikan yang ditemukan di Pulau Liki (M. hexagona, S. caudimaculatum dan $C$. urodeta) dan satu spesies ikan yang berasal dari Pulau Miossu (L. xanthopinnis). Mikroplastik ditemukan pada insang dan saluran pencernaan pada dua jenis ikan dari Pulau Befondi yaitu L. kasmira dan $B$. undulatus, sedangkan pada jenis $L$. gibbus dan $S$. caudimaculatum fiber hanya ditemukan pada saluran pencernaan atau hanya di insang (Figure 3).

Table 1. Morphometric data of the fishes from the three small outer islands of Papua $(n=12)$.

\begin{tabular}{|c|c|c|c|c|}
\hline $\begin{array}{c}\text { Fish species } \\
\text { (number of samples) }\end{array}$ & Length $(\mathrm{cm})$ & Weight $(g)$ & $\begin{array}{c}\text { Gill } \\
(\mathrm{g} d r y \text { weight })\end{array}$ & $\begin{array}{c}\text { Gastrointestinal } \\
\text { track } \\
\text { (g dry weight) }\end{array}$ \\
\hline \multicolumn{5}{|l|}{ Liki Island } \\
\hline M. hexagona (3) & $60.05 \pm 19.21$ & $15.17 \pm 1.44$ & $0.71 \pm 0.20$ & $0.85 \pm 0.37$ \\
\hline S. caudimaculatum (1) & 37.76 & 13 & 0.26 & 0.47 \\
\hline C. urodeta $(1)$ & 56.75 & 16 & 0.47 & 0.52 \\
\hline \multicolumn{5}{|l|}{ Befondi Island } \\
\hline L. kasmira (2) & $156.51 \pm 9.89$ & $22.75 \pm 1.06$ & $0.75 \pm 0.70$ & $0.82 \pm 0.18$ \\
\hline B. undulates (1) & 197.75 & 18.5 & 1.68 & 6.75 \\
\hline L. gibbus (1) & 198.35 & 24 & 0.50 & 1.25 \\
\hline S. caudimaculatum (1) & 81.61 & 17.50 & 0.64 & 0.61 \\
\hline \multicolumn{5}{|l|}{ Miossu Island } \\
\hline L. xanthopinnis (2) & $64.20 \pm 3.61$ & $15.75 \pm 0.35$ & $0.35 \pm 0.20$ & $0.53 \pm 0.11$ \\
\hline
\end{tabular}

Table 2. The abundance of fiber from each of fish species.

\begin{tabular}{rlcc}
\hline Island & \multicolumn{1}{c}{ Fish species } & No. of samples & $\begin{array}{c}\text { Total abundance } \\
\left(\text { particle }^{-1}\right)\end{array}$ \\
\hline Liki & M. hexagona & 3 & $11.10 \pm 4.24$ \\
& S. caudimaculatum & 1 & 28.30 \\
\multirow{3}{*}{ Befondi } & C. urodeta & 1 & 12.17 \\
& L. kasmira & 2 & $9.94 \pm 0.97$ \\
& B. undulatus & 1 & 2.08 \\
& L. gibbus & 1 & 1.60 \\
Miossu & S. caudimaculatum & 1 & 1.57 \\
\hline
\end{tabular}




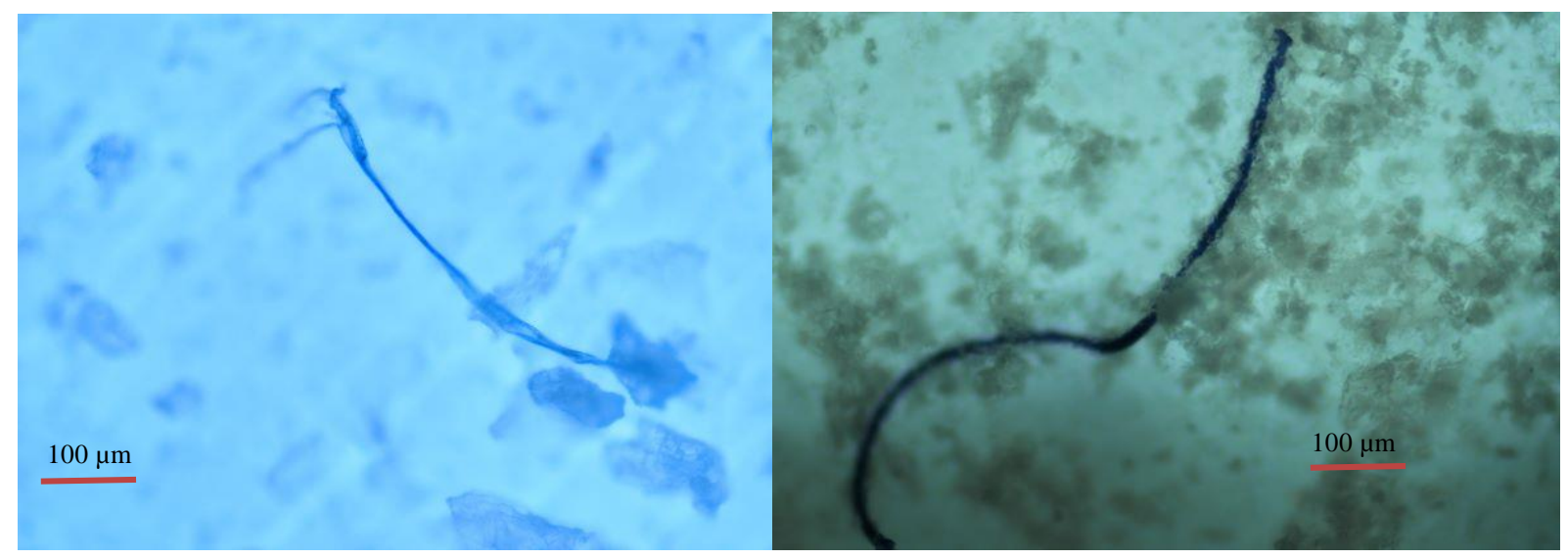

Figure 2. Fiber type of microplastic found in the fish samples.
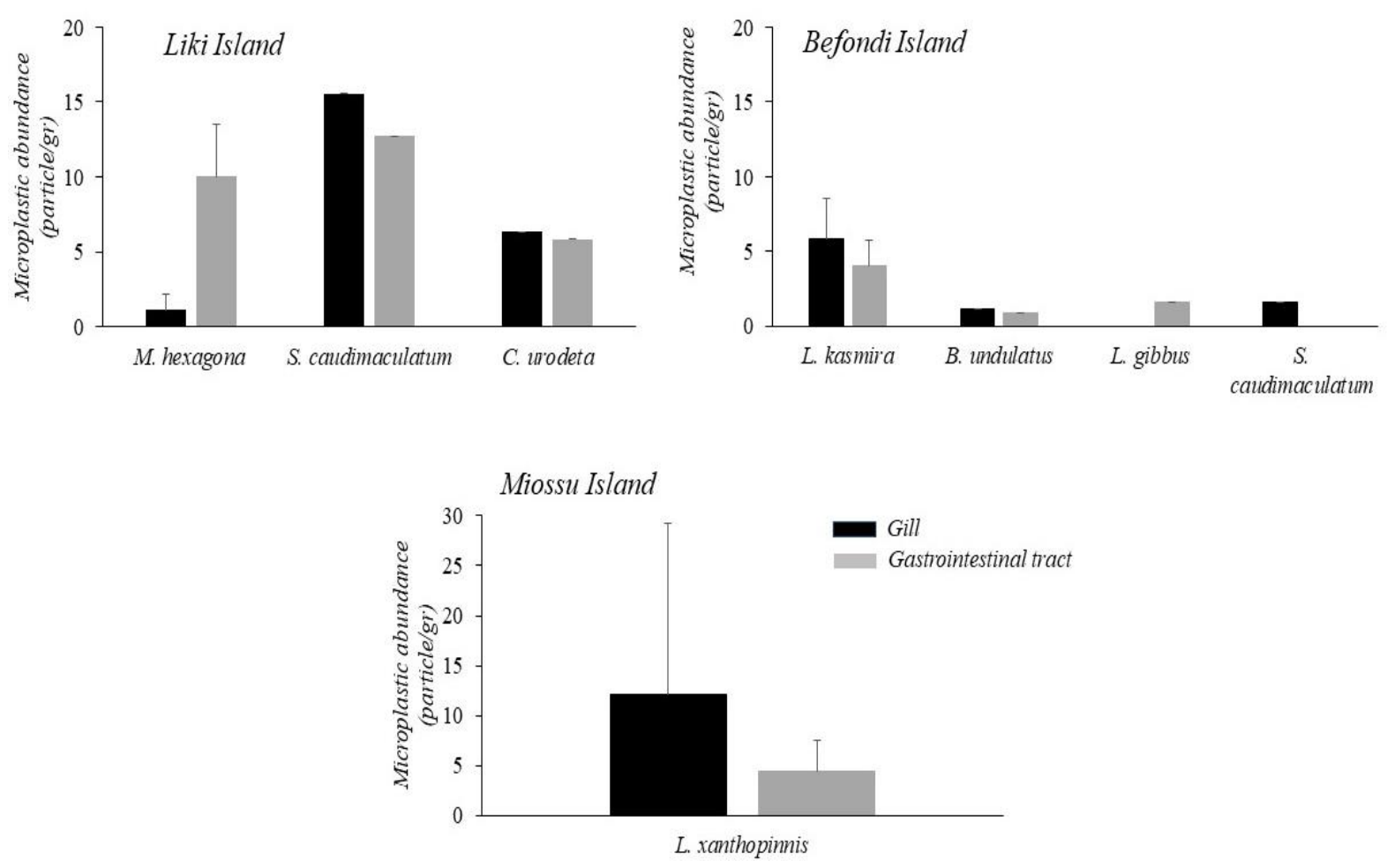

Figure 3. The abundance of fiber found in each fish species from the three islands.

Sebagian besar jenis fiber ditemukan lebih tinggi pada insang dibandingkan pada saluran pencernaan, kecuali pada $M$. hexagona dari Pulau Liki yang memiliki kelimpahan fiber di saluran pencernaan jauh lebih tinggi dibandingkan pada insang. Fiber pada insang dan saluran pencernaan pada spesies L. kasmira dari Pulau Befondi ditemukan dengan kelimpahan jenis yang hampir sama.
Abbasi et al. (2018) juga menemukan hasil serupa bahwa mikroplastik lebih banyak terdapat pada insang dibandingkan pada saluran pencernaan ikan pelagis dan demersal yang ditangkap di perairan pantai Teluk Persia. Namun jika dibandingkan dengan organ tubuh yang lain seperti liver, daging dan juga kulit ikan, insang dan saluran pencernaan cenderung mengakumulasi mikroplastik lebih tinggi. Sebaliknya, Su et al. 
(2019) menemukan kelimpahan mikroplastik yang lebih tinggi di saluran pencernaan dibandingkan di insang ikan komersil yang ditangkap di Hangzhou Bay dan Yangtze Estuary. Keberadaan mikroplastik jenis fiber pada insang maupun saluran pencernaan ikan cukup bervariasi dan hal ini diduga karena perbedaan fungsi dari setiap organ dan interaksinya dengan perairan sebagai sumber mikroplastik. Mikroplastik yang masuk ke dalam insang ikan merupakan mikroplastik yang bersumber langsung dari perairan sebagai bagian dari proses pernapasan ikan. Dalam proses pertukaran gas, ikan menyaring air dari lingkungan untuk mendapatkan oksigen dan saat proses ini berlangsung mikroplastik yang berada di perairan dapat terjebak pada bagian insang. Mikroplastik yang ditemukan di saluran pencernaan ikan dapat berasal dari perairan langsung dalam proses ikan mendapatkan makanan maupun berasal dari rantai makanannya (biomagnifikasi). Saluran pencernaan disebut sebagai tempat pengumpulan akhir dari mikroplastik terutama yang berukuran lebih besar yang tidak bisa dikeluarkan melalui feses ikan (Neves et al., 2015; Jabeen et al., 2017).

Kelimpahan jenis fiber tertinggi baik pada insang maupun saluran pencernaan ditemukan pada spesies $S$. caudimaculatum yang ditangkap dari Pulau Liki (15,58 partikel/g pada insang dan 12,73 partikel/g pada saluran pencernaan). Spesies lainnya cenderung memiliki kelimpahan jenis fiber yang hampir sama yaitu pada kisaran kurang dari 10 partikel/g pada insang dan saluran pencernaan. Jika dibandingkan dengan ukuran ikan (Table 1), S. caudimaculatum yang berasal dari Pulau Liki termasuk berukuran kecil dengan kelimpahan mikroplastik yang tinggi, sedangkan ikan-ikan yang ditangkap dari Pulau Befondi cenderung memiliki ukuran yang lebih besar, namun kelimpahan mikroplastik yang lebih rendah. Hal ini membuktikan tidak ada hubungan antara ukuran ikan dengan keberadaan mikroplastik pada organ tubuh ikan (Bessa et al., 2018; Giani et al., 2019).

Berdasarkan ukurannya, persentase mikroplastik yang ditemukan pada setiap jenis ikan didominasi oleh jenis fiber pada ukuran $>1000 \mu \mathrm{m}$ baik pada insang maupun saluran pencernaan (Table 3). Mikroplastik hanya ditemukan pada insang $S$. caudimaculatum dari Pulau Befondi dan semua jenis fiber yang ditemukan berukuran $>1000 \mu \mathrm{m}(100 \%)$. Rata-rata persentase jenis fiber pada insang $M$. hexagona dari Pulau Liki juga semuanya ditemukan dengan ukuran > $1000 \mu \mathrm{m}$. Persentase mikroplastik ditemukan paling sedikit pada fiber dengan ukuran paling kecil yaitu $<300 \mu \mathrm{m}$, hanya pada saluran pencernaan ikan $M$. hexagona dari Pulau Liki. Persentase jenis fiber ditemukan pada semua kategori ukuran pada S. caudimaculatum dari Pulau Liki, $L$. kasmira dari Pulau Befondi dan $L$. xanthopinnis dari Pulau Miossu, baik pada

Table 3. Percentage of fiber found in gut and gastrointestinal tract of sampled fishes according to the size.

\begin{tabular}{|c|c|c|c|c|c|c|c|c|}
\hline \multirow[b]{3}{*}{$\begin{array}{c}\text { Fish species } \\
\text { (number of samples) }\end{array}$} & \multicolumn{8}{|c|}{ Percentage of fiber $(\%)$} \\
\hline & \multicolumn{2}{|c|}{$<300 \mu \mathrm{m}$} & \multicolumn{2}{|c|}{$300-500 \mu \mathrm{m}$} & \multicolumn{2}{|c|}{$500-1000 \mu \mathrm{m}$} & \multicolumn{2}{|c|}{$>1000 \mu \mathrm{m}$} \\
\hline & Gill & $\begin{array}{c}\text { Gastroi } \\
\text { ntestinal } \\
\text { tract }\end{array}$ & Gill & $\begin{array}{c}\text { Gastroi } \\
\text { ntestinal } \\
\text { tract }\end{array}$ & Gill & $\begin{array}{c}\text { Gastroi } \\
\text { ntestina } \\
\text { l tract }\end{array}$ & Gill & $\begin{array}{c}\text { Gastro } \\
\text { intesti } \\
\text { nal } \\
\text { tract }\end{array}$ \\
\hline $\begin{array}{l}\text { Liki Island } \\
\text { M. hexagona (3) }\end{array}$ & 0 & $\begin{array}{c}21.76 \pm \\
13.91\end{array}$ & 0 & $\begin{array}{l}11.57 \pm \\
11.14\end{array}$ & 0 & $\begin{array}{c}17.13 \pm \\
4.88\end{array}$ & $\begin{array}{c}66.67 \pm \\
57.74\end{array}$ & $\begin{array}{c}49.54 \pm \\
15.24\end{array}$ \\
\hline S. caudimaculatum (1) & 0 & 0 & 50 & 16.67 & 25 & 16.67 & 25 & 66.67 \\
\hline C. urodeta (1) & 0 & 0 & 0 & 0 & 33.33 & 66.67 & 66.67 & 33.33 \\
\hline
\end{tabular}




\begin{tabular}{|c|c|c|c|c|c|c|c|c|}
\hline \multirow[b]{3}{*}{$\begin{array}{c}\text { Fish species } \\
\text { (number of samples) }\end{array}$} & \multicolumn{8}{|c|}{ Percentage of fiber (\%) } \\
\hline & \multicolumn{2}{|c|}{$<300 \mu m$} & \multicolumn{2}{|c|}{$300-500 \mu \mathrm{m}$} & \multicolumn{2}{|c|}{$500-1000 \mu \mathrm{m}$} & \multicolumn{2}{|c|}{$>1000 \mu \mathrm{m}$} \\
\hline & Gill & $\begin{array}{c}\text { Gastroi } \\
\text { ntestinal } \\
\text { tract }\end{array}$ & Gill & $\begin{array}{c}\text { Gastroi } \\
\text { ntestinal } \\
\text { tract }\end{array}$ & Gill & $\begin{array}{c}\text { Gastroi } \\
\text { ntestina } \\
\text { l tract }\end{array}$ & Gill & $\begin{array}{c}\text { Gastro } \\
\text { intesti } \\
\text { nal } \\
\text { tract }\end{array}$ \\
\hline Befondi Island & & & & & & & & \\
\hline L. kasmira (2) & 0 & 0 & $\begin{array}{l}40 \pm \\
56.57\end{array}$ & $\begin{array}{c}25 \pm \\
35.36\end{array}$ & $\begin{array}{c}25 \pm \\
35.36\end{array}$ & $\begin{array}{c}65 \pm \\
21.21\end{array}$ & $\begin{array}{c}35 \pm \\
21.21\end{array}$ & $\begin{array}{c}10 \pm \\
14.14\end{array}$ \\
\hline B. undulatus (1) & 0 & 0 & 0 & 33.33 & 50 & 33.33 & 50 & 33.33 \\
\hline L. gibbus (1) & 0 & 0 & 0 & 50 & 0 & 0 & 0 & 50 \\
\hline $\begin{array}{l}\text { S. caudimaculatum (1) } \\
\text { Miossu Island }\end{array}$ & 0 & 0 & 0 & 0 & 0 & 0 & 100 & 0 \\
\hline L. xanthopinnis (2) & 0 & 0 & 0 & $\begin{array}{l}12.50 \pm \\
17.68\end{array}$ & $\begin{array}{c}20 \pm \\
28.28 \\
\end{array}$ & $\begin{array}{c}50 \pm \\
70.71\end{array}$ & $\begin{array}{c}30 \pm \\
42.43\end{array}$ & $\begin{array}{c}37.50 \pm \\
53.03\end{array}$ \\
\hline
\end{tabular}

insang maupun saluran pencernaannya. Hasil penelitian ini sesuai dengan hasil yang ditemukan oleh Abassi et al. (2018) bahwa dominansi mikroplastik berukuran besar cenderung ditemukan pada organ pencernaan dibandingkan dengan organ tubuh yang lain. Lebih lanjut, Su et al. (2019) menemukan fiber dengan ukuran yang lebih besar (> 1 $\mathrm{mm})$ pada saluran pencernaan ikan, sedangkan fiber dengan ukuran yang lebih kecil $(<1 \mathrm{~mm})$ pada insang. Namun demikian, secara spesifik belum ada yang menjelaskan pengaruh perbedaan ukuran mikroplastik yang ditemukan pada organ tubuh ikan sehingga diperlukan penelitian lebih lanjut.

\section{KESIMPULAN}

Berdasarkan hasil penelitian ini, mikroplastik ditemukan pada semua jenis ikan yang diteliti dan didominasi oleh jenis fiber. Hal ini karena fiber termasuk jenis mikroplastik yang ditemukan melimpah di perairan, sehingga potensi masuknya ke dalam tubuh ikan juga lebih besar. Meskipun, Pulau Liki, Befondi dan Miossu merupakan pulau-pulau kecil dan terluar di Wilayah Papua, namun masukan mikroplastik tetap dapat terjadi dan berdampak terhadap ikan di perairan. Mikroplastik ditemukan pada insang dan saluran pencernaan ikan dengan komposisi ukuran yang bervariasi. Sebagian besar mikroplastik jenis fiber ditemukan lebih tinggi pada insang dibandingkan pada saluran pencernaan. Perbedaan ini diduga karena perbedaan fungsi setiap organ dan proses masuknya mikroplastik dari perairan ke bagian organ tersebut masing-masing.

\section{UCAPAN TERIMA KASIH}

Terimakasih diucapkan kepada seluruh tim Ekspedisi Nusa Manggala dari P2O LIPI dan juga kru kapal Baruna Jaya VIII atas kesempatan penelitian yang diberikan dan juga bantuan selama proses sampling di lapang. Ucapan terimakasih juga penulis sampaikan kepada teknisi dan staf laboratorium Kimia Laut dan Ekotoksikologi, P2O LIPI atas bantuannya selama proses analisis laboratorium.

\section{DAFTAR PUSTAKA}

Abbasi, S., N. Soltani, B. Keshavarzi, F. Moore, A. Turner, \& M. Hassanaghaei. 2018. Microplastics in different tissues of fish and prawn from the Musa Estuary, Persian Gulf. Chemosphere, 205: 80-87.

https://doi.org/10.1016/j.chemosphere .2018.04.076

Allen, G.R., R. Steene, P. Humann, \& N. Deloach. 2003. Reef fish identification: Tropical Pacific. New 
World Publication. Jacksonville, Florida. 483 p.

Andrady, A.L. 2011. Microplastics in the marine environment. Marine Pollution Bulletin, 62: 1596-1605. https://doi.org/10.1016/j.marpolbul.20 11.05.030

Baalkhuyur, F.M., E.J.A. Bin Dohaish, M.E.A. Elhalwagy, N.M. Alikunhi, A.M. Al Suwailem, A. Røstad, D.J. Coker, M.L. Berumen, \& C.M. Duarte. 2018. Microplastic in the gastrointestinal tract of fishes along the Saudi Arabian Red Sea coast. Marine Pollution Bulletin, 131: 407415.

https://doi.org/10.1016/j.marpolbul.20 18.04.040

Bessa, F., P. Barria, J.M. Neto, J.P.G.L. Frias, V. Otero, P. Sobral, \& J.C. Marques. 2018. Occurence of microplastics in commercial fish from a natural estuarine environment. Marine Pollution Bulletin, 128: 575-584.

http://doi.org/10.1016/j.marpolbul.20 18.01.044

Cincinelli, A., C. Scopetani, D. Chelazzi, E. Lombardini, T. Martellini, A. Katsoyiannis, M.C. Fossi, \& S. Corsolini. 2017. Microplastic in the surface waters of the Ross Sea (Antarctica): Occurrence, distribution and characterization by FTIR. Chemosphere, 175: 391-400. https://doi.org/10.1016/j.chemosphere .2017 .02 .024

Connors, E.J. 2017. Distribution and biological implications of plastic pollution on the fringing reef of Mo'orea, French Polynesia. PeerJ 5, e3733.

https://doi.org/10.7717/peerj.3733

Cordova, M.R., T.A. Hadi, \& B. Prayudha. 2018. Occurrence and abundance of microplastics in coral reef sediment: a case study in Sekotong, LombokIndonesia. AES Bioflux, 10: 23-29. http://www.aes.bioflux.com.ro/docs/2 018.23-29.pdf

Cordova, M.R. \& A.J. Wahyudi. 2016. Microplastic in the deep-sea sediment of Southwestern Sumatran Waters. Marine Research in Indonesia, 41: 27-35. https://doi.org/10.14203/mri.v41i1.99

Dai, Z., H. Zhang, Q. Zhou, Y. Tian, T. Chen, C. Tu, C. Fu, \& Y. Luo. 2018. Occurrence of microplastics in the water column and sediment in an inland sea affected by intensive anthropogenic activities. Environmental Pollution, 242: 15571565.

https://doi.org/10.1016/j.envpol.2018. 07.131

Frère, L., I. Paul-Pont, E. Rinnert, S. Petton, J. Jaffré, I. Bihannic, P. Soudant, C. Lambert, \& A. Huvet. 2017. Influence of environmental and anthropogenic factors on the composition, concentration and spatial distribution of microplastics: A case study of the Bay of Brest (Brittany, France). Environmental Pollution, 225: 211222. https://doi.org/10.1016/j.envpol.2017. 03.023

Giani, D., M. Baini, M. Galli, S. Casini, \& M.C. Fossi. 2019. Microplastics occurrence in edible fish species (Mullus barbatus and Merluccius merluccius) collected in three different geographical sub-areas of the Mediterranean Sea. Marine Pollution Bulletin, 140: 129-137. https://doi.org/10.1016/j.marpolbul.20 19.01 .005

Group of Experts on the Scientific Aspects of Marine Environmental Protection (GESAMP). 2016. Sources, fate and effects of microplastics in the marine environment: part two of a global assessment (Kershaw, P. J., and C.M Rochman, eds). 
IOC/UNIDO/WMO/IAEA/UN/UNEP /UNDP Joint Group of Experts on the Scientific Aspects of Marine Environmental Protection). Report Studies, GESAMP No. 93, $220 \mathrm{p}$.

Group of Experts on the Scientific Aspects of Marine Environmental Protection (GESAMP). 2015. Sources, fate and effects of microplastics in the marine environment: a global assessment (Kershaw, P. J., ed.). (IMO/FAO/UNESCOIOC/UNIDO/WMO/IAEA/UN/UNEP /UNDP Joint Group of Experts on the Scientific Aspects of Marine Environmental Protection). Report Studies, GESAMP No. 90, 96 p.

Hidalgo-Ruz, V., L. Gutow, R.C. Thompson, \& M. Thiel. 2012. Microplastics in the Marine Environment: A Review of the Methods Used for Identification and Quantification. Environmental Science and Technology, 46: 3060-3075. https://doi.org/10.1021/es2031505

Imhof, H.K., R. Sigl, E. Brauer, S. Feyl, P. Giesemann, S. Klink, K. Leupolz, M.G.J. Löder, L.A. Löschel, J. Missun, S. Muszynski, A.F.R.M. Ramsperger, I. Schrank, S. Speck, S. Steibl, B. Trotter, I. Winter, \& C. Laforsch. 2017. Spatial and temporal variation of macro-, meso- and microplastic abundance on a remote coral island of the Maldives, Indian Ocean. Marine Pollution Bulletin, 116: 340-347. https://doi.org/10.1016/j.marpolbul.20 17.01.010

Isobe, A., K. Uchiyama-Matsumoto, K. Uchida, \& T. Tokai. 2017. Microplastics in the Southern Ocean. Marine Pollution Bulletin, 114: 623626.

https://doi.org/10.1016/j.marpolbul.20 16.09.037

Iwasaki, S., A. Isobe, S. Kako, K. Uchida, \& T. Tokai. 2017. Fate of microplastics and mesoplastics carried by surface currents and wind waves: A numerical model approach in the Sea of Japan. Marine Pollution Bulletin, 121: 85-96.

https://doi.org/10.1016/j.marpolbul.20 17.05.057

Jabeen, K., L. Su, J. Li, D. Yang, C. Tong, J. Mu, \& H. Shi. 2017. Microplastics and mesoplastics in fish from coastal and fresh waters of China. Environmental Pollution, 221: 141149.

https://doi.org/10.1016/j.envpol.2016. 11.055

Mohamed Nor., N.H. \& J.P. Obbard. 2014. Microplastics in Singapore's coastal mangrove ecosystems. Marine Pollution Bulletin, 79: 278-283. https://doi.org/10.1016/j.marpolbul.20 13.11.025

Murphy, F., M. Russell, C. Ewins, \& B. Quinn. 2017. The uptake of macroplastic \& microplastic by demersal \& pelagic fish in the Northeast Atlantic around Scotland. Marine Pollution Bulletin, 122: 353359.

https://doi.org/10.1016/j.marpolbul.20 17.06.073

Neves, D., P. Sobral, J.L. Ferreira, \& T. Pereira. 2015. Ingestion of microplastics by commercial fish off the Portuguese coast. Marine Pollution Bulletin, 101: 119-126.

https://doi.org/10.1016/j.marpolbul.20 15.11.008

Pozo, K., V. Gomez, M. Torres, L. Vera, D. Nuñez, P. Oyarzún, G. Mendoza, B. Clarke, M.C. Fossi, M. Baini, P. Přibylová, \& J. Klánová. 2019. Presence and characterization of microplastics in fish of commercial importance from the Biobío region in central Chile. Marine Pollution Bulletin, 140: 315-319.

https://doi.org/10.1016/j.marpolbul.20 19.01.025 
Sarasita, D., A. Yunanto, \& D. Yona. 2020. Kandungan mikroplastik pada empat jenis ikan ekonomis penting di perairan Selat Bali. J. Iktiologi Indonesia, 20: 1-12.

https://doi.org/10.32491/jii.v20i1.508

Savoca, S., G. Capillo, M. Mancuso, T. Bottari, R. Crupi, C. Branca, V. Romano, C. Faggio, G. D’Angelo, \& N. Spanò. 2019. Microplastics occurrence in the Tyrrhenian waters and in the gastrointestinal tract of two congener species of seabreams. Environmental Toxicology and Pharmacology, 67: 35-41. https://doi.org/10.1016/j.etap.2019.01 .011

Su, L., H. Deng, B. Li, Q. Chen, V. Pettigrove, C. Wu, \& H. Shi. 2019. The occurrence of microplastic in specific organs in commercially caught fishes from coast and estuary area of east China. J. Hazardous Material, 365: 716-724.

https://doi.org/10.1016/j.jhazmat.201 8.11.024

Woods, M.N., M.E. Stack, D.M. Fields, S.D. Shaw, \& P.A. Matrai. 2018. Microplastic fiber uptake, ingestion, and egestion rates in the blue mussel (Mytilus edulis). Marine Pollution Bulletin, 137: 638-645.

https://doi.org/10.1016/j.marpolbul.20 18.10.061
Yona, D., S.H.J. Sari, F. Iranawati, S. Bachri, \& W.C. Ayuningtyas. 2019. Microplastics in the surface sediments from the eastern waters of Java Sea, Indonesia. F1000Research, 8: 98. https://doi.org/10.12688/f1000researc h. 17103.1

Zhao, J., W. Ran, J. Teng, Y. Liu, H. Liu, X. Yin, R. Cao, \& Q. Wang. 2018. Microplastic pollution in sediments from the Bohai Sea and the Yellow Sea, China. Science of Total Environment, 640-641: 637-645. https://doi.org/10.1016/j.scitotenv.201 8.05.346

Zhu, L., H. Bai, B. Chen, X. Sun, K. Qu, \& B. Xia. 2018. Microplastic pollution in North Yellow Sea, China: Observations on occurrence, distribution and identification. Science of Total Environment, 636: 20-29.

https://doi.org/10.1016/j.scitotenv.201 8.04.182

Zobkov, M. \& E. Esiukova. 2017. Microplastics in Baltic bottom sediments: Quantification procedures and first results. Marine Pollution Bulletin, 114: 724-732.

https://doi.org/10.1016/j.marpolbul.20 16.10 .06

Received : 15 May 2019

Reviewed : 12 July 2020

Accepted : 19 August 2020 
